\title{
A Case Study From Ramannapeta Mandal, Nalgonda, Telangana, India: Fluoride Contamination of Ground Water
}

Dr.G.Machender Ganaboina ( $\sim$ machender_geo@yahoo.co.in )

Mahatma Gandhi University

Narsimha Kota

Osmania University

\section{Research Article}

Keywords: Fluoride Contamination, Groundwater, Remote sensing, Ramannapeta Mandal

Posted Date: July 30th, 2021

DOI: https://doi.org/10.21203/rs.3.rs-681568/v1

License: () (7) This work is licensed under a Creative Commons Attribution 4.0 International License. Read Full License 


\section{Abstract}

The groundwater quality evaluation for fluoride element was studied in Ramannapeta Mandal, Nalgonda District, and Telangana State, India. The water samples were collected in pre and post monsoon seasons in the year of 2015-2016 from hand pumps bore wells or dug wells in the villages of Ramannapeta Mandal. The collected water samples were analyzed within a week. The Spatial distributions of fluoride maps were prepared with the help of the Remote Sensing Imaginary (RSI) and Geographical Information System (GIS) techniques. The range of fluoride in the study area varied from 0.6 to 5.6 ppm whereas the maximum permissible limit in drinking water is 1.5 ppm (As per Bureau of Indian Standard (BIS) guideline-IS: 10500: 1991). The high contamination 4.0$5.5 \mathrm{ppm}$ of fluoride in drinking water was observed in Siripuram, Dubbaka villages. During the study, it was found that the most of villages in Ramannapeta Mandal are affected with high fluoride content in drinking water in the range of 1.5-3.0 ppm. Nalgonda district including Ramannapeta Mandal is underlain by different rocks such as granites ( $80 \%)$, gneisses, dolerite, dykes (10\%), older metamorphic and intrusive (10\%). The lock of freshwater exchange due to periodical drought conditions, the granitic rocks and the arid climate of the region are the factors for the higher incidence of fluoride in the groundwater resources. The constructions of rain water harvesting structures are proposed to minimize fluoride content in drinking water.

\section{Introduction}

Groundwater is the major source for drinking in most parts of the world, as it is available cheaply near to door step and free from pathogenic bacteria. Good quality of drinking water is essential for human life. The goal of Government is to provide every person with adequate safe water for drinking, cooking and other domestic uses. The spatio-temporal variations in rainfall, regional distribution in geological formations and geomorphic composition of various units have led to uneven occurrence and distribution of groundwater resources.

There are few chemical contaminations of drinking water that can lead to severe health problems. Especially fluoride is a major concern; the recommended concentration of fluoride in drinking water is $1.5 \mathrm{mg} / \mathrm{l}$ (WHO; 1984). Seawater typically contains about $1 \mathrm{mg} / \mathrm{l}$ of $\mathrm{F}^{-}$where rivers and lakes generally exhibit less than $0.5 \mathrm{mg} / \mathrm{l}$. Low or high concentrations of fluoride is possible in groundwater, depending on the existence of nature of the rocks and fluoride-bearing minerals. The high fluoride containing water occurs in large and extensive geographical belts associated with sediments of marine origin in mountainous areas, volcanic rocks, granitic and gneissic rocks.

In India, high groundwater fluoride content associated with igneous and metamorphic rocks such as granites and gneisses have been reported. Endemic fluorosis is still a challenging and extensively studied national health problem. The most seriously affected areas in India are Telangana, Andhra Pradesh, Punjab, Haryana, Rajasthan, Gujarat, Tamil Nadu, Orissa, Punjab and Uttar Pradesh etc (Kumaran, et al., 1971; Teotia et al., 1984). The high concentration of fluoride in drinking water was reported in 19 states and territories which include 177 districts. The highest concentration observed to date in India is 48 mg/l in Rewari District of Haryana.

Groundwater is the primary source of potable water supply in rural India. It is not possible to estimate the number of people at risk with high fluoride in drinking water. This is because of the difficulty of sampling groundwater from India's many millions of hand pumps. In these states, 10 to $25 \%$ of the rural population has been estimated to be at risk, and approximately $60-70$ million people are influenced by fluoride contaminated groundwater. About $60 \%$ of land comes under irrigation of groundwater; this is also other main reason of producing high fluoride food. The rainfall is the source of recharge of groundwater, geomorphology plays a vital role in controlling distribution of precipitation, runoff, and infiltration contributing to recharge.

Fluorosis is an endemic disease. An endemic disease found in a certain geographic region or in a specific race of people. The fluoride in potable water not exceed to $1 \mathrm{mg} / \mathrm{L}$. High $\mathrm{F}^{-}$concentration in drinking water is main concern, because of its negative impact on human health. The fluoride arises into the water from the geological crust. The main potential health risks from fluoride are considered to be fluorosis or bone disease. Based on body tissues influenced by fluoride, fluorosis is categorized into Dental, Skeletal and Non-Skeletal fluorosis. Irrespective of age and gender, anybody can become victims of Fluorosis. Fluoride content range in drinking water and how it effects on human health is listed in Table 1.

Table 1

Fluorosis Hazards chart.

\begin{tabular}{|lll|}
\hline & $\mathbf{F}^{-}$in drinking water $(\mathrm{mg} / \mathrm{L})$ & Effects on human health \\
\hline 1 & 0.6 & Dental caries \\
\hline 2 & $0.6-1.2$ & Development of normal bones \& teeth \\
3 & $1.2-2.0$ & Mottled enamel \\
\hline 4 & $2.0-4.0$ & Dental fluorosis \\
\hline 5 & $4.0-8.0$ & Skeletal fluorosis \\
6 & $8.0-10.0$ & Mild crippling Skeletal \\
\hline 7 & Above 10.0 & Cripping Skeletal Fluorosis \\
\hline
\end{tabular}

In the present study, groundwater quality evaluation was carried out in the villages of Ramannapeta Mandal, Telangana State, India. In order to evaluate the spatial distribution of fluoride concentration, 72 water samples were collected from 36 places before and after monsoon season. The Spatial distributions of fluoride maps were prepared with the help of the Remote Sensing Imaginary (RSI) and Geography Information System (GIS) techniques. The relations between fluoride distribution and physiology, hydrogeology were correlated. 


\section{Description of Study Area}

The study area is located in northern part of the district of Nalgonda, Telangana State, India. It lies in between $78.59^{\circ}-79.15^{\circ}$ of East-longitudes and $17.14^{\circ}-17.22^{\circ}$ of North- latitude with an average elevation of 322 meters. It falls in the SOI Toposheets No. 56 0/3. The location of the study area is shown in Fig. 1. As per 2011 census, the population of the area is 51,534 while the urban population is 10,202 . The area experiences semi-arid climate, the average temperature varies from $17^{\circ} \mathrm{C}$ in winter (December-January) to $45^{\circ} \mathrm{C}$ in summer (March-May).

The average annual rainfall is $649 \mathrm{~mm}$ both by northeast and southwest monsoons. $80 \%$ of the people from the study area use bore and dug wells water for drinking, cooking and other domestic uses. The depth of the bore wells varied between 90 and 300 feet. The area around 228 sq.km was covered and 36 water samples were collected in cleaned and sterilized glass bottles. All the collected samples were analyzed within week in the laboratory.

\section{Remote Sensing and GIS}

The Remote Sensing imagery with its synoptic coverage acts as a tool for finding suitable solution when combined with conventional data. Hydro-geomorphic maps were prepared by integrating the lithology, landforms, and structural fabric and hydrology layers using Remote Sensing and GIS techniques, the scale range of 1:10,000. The satellite data has been used for updating of drainage and surface water bodies. The IRS P6 LISS-IV is a multi-spectral high resolution camera with a spatial resolution of $5.8 \mathrm{~m}$ at nadir. Satellite image of the study area is shown in Fig. 2.

\section{Physiography of the study area}

Ramannapeta Mandal is located in the northern of the District. The study area is surrounded by Mothkur, Valigonda, Narketpalli, Chityala and Choutuppal Mandals. The elevation of the study area varies from 225 to $370 \mathrm{~m}$ to mean sea level (MSL). A major part of the Mandal is covered by the Musi river basin which rises in Dubbaka and Nidanpalle Hills. The river flows from South to North of the Mandal. The river passes through Valigonda, Ramannapeta towards Nakrekal Mandal; it joins the Krishna River near Wadapalli.

From the satellite imaginary studies, it was observed that $76 \%$ of the study area covered by major landforms in granitic rocks which are pediplains. About $14 \%$ of the area covered by pediment and Inselberg zone, $4 \%$ of the area covered by valley zones and the remaining area covered by highly weathered hills and water bodies.

\section{Drainage \& Rainfall}

The drainage pattern of the study area is mainly dendritic drainage, all the water streams flow from Southwest to Northeast direction. Nalgonda district has an average rainfall of $649 \mathrm{~mm}$ during years of 2004-2015.The most rainfall is received through the Southwest monsoon during the period of June-September. An average annual temperature of the study area varies from $17^{\circ} \mathrm{C}$ in winter (December-January) to $45^{\circ} \mathrm{C}$ in summer (March-May).

\section{Geology of the study area}

The study area underlined by the variety of granite and gneisses rocks which are intruded by dolerite dykes/quartz veins. Granite, old and hard rocks, are widely distributed throughout the area. The nature of granite varies in the study area, grey to pink, medium to coarse granite, porphyritic or non-porphyritic and massive. The granitoid rocks are complex which associated with profuse injections of aplite, fine grained quartzo-feldspathic veins and pegmatite, quartz veins and reefs.

From the stratigraphical studies, the study area predominantly exposes rocks of Peninsular Gneissic Complex (PGC) along with enclaves of basic dykes (Proterozoic). The PGC includes mainly two varieties of granitoid rocks i.e. older granite gneiss and younger granite (alkali feldspar). The most of the lineaments/faults identified are aligned in the direction of Northeast to Southwest and North-northeast to South-southwest. Generally dolerite dykes appear to be very hard and compact and poorly devoid of fractures, whereas the Pegmatite veins / Quartz reefs are highly fractured.

\section{Hydrogeology}

The majority of the area occupies with hard rock like gneissic complex which includes granite/gneisses, dolerite dykes. Very little area covered with other formations. Even though, the absence of primary porosity in hard rock formations, the aquifer system developed because of secondary porosity due to various tectonic disturbances and weathering activity. The deeper aquifer system developed due to major faults, joints, fractures, crevices, shear zones etc. It was observed that the groundwater prospect of the study area is in the range of 100-200 lpm in moderately weathered granite gneiss/granitoid rocks and valleys whereas the range is $50-100 \mathrm{lpm}$ in shallow weathered granite gneiss/granitoid rocks and valleys. The availability of groundwater is in the range of $10-50$ Ipm and low to poor (0 to $10 \mathrm{lpm}$ ) in the pediment zones of granitic rocks and highly dissected hills/plateaus respectively.

\section{Materials And Methods}

Groundwater samples were collected in polyethylene bottles from pre-identified places of the villages of Ramannapeta Mandal. All the samples were collected in pre and post monsoon season, 2015-2016.The collected samples were analyzed within a week. Fluoride was analyzed using Lovibond PC Spectrophotometer (SN 100537, Germany) following the method of SPANDS colorimetric method. Various other water quality parameters such as pH, electrical conductivity, total dissolved solids, total hardness, total alkalinity, sodium, potassium, calcium, magnesium, carbonate, bicarbonate, chloride, and sulfate concentrations were measured. The techniques and methods followed for the collection, preservation, analysis, and interpretation are those given by (Rainwater and Thatcher 1960), (Brown et al. 1970), (Karanth, 1989), (Hem,1991), (APHA,1992), and (BIS, 2003). 
The data is segregated into pre and post monsoon seasons based on date of collection of samples and these results are listed in Table 2 and Table 3 respectively.

Table 2

Chemical Analysis of water samples collected during pre-monsoon season

\begin{tabular}{|c|c|c|c|c|c|c|c|c|c|c|c|c|c|c|c|c|}
\hline S.N. & S_No & Village & DMV_Code & LAT & LONG & SourceType & $\mathrm{pH}$ & EC & TDS & $\begin{array}{l}\mathrm{Ca} \\
+2\end{array}$ & $\begin{array}{l}\mathrm{Mg} \\
+2\end{array}$ & $\mathrm{Na}+$ & $\mathrm{K}+$ & TH & $\begin{array}{l}\mathrm{CO}^{-} \\
-\end{array}$ & r \\
\hline 1 & RP_01 & Dubbaka & 2320014 & 17.31 & 79.14 & BW & 7.1 & 3600 & 2304 & 110 & 65 & 198 & 2.0 & 543 & 0 & 1 \\
\hline 2 & RP_02 & Dubbaka & 2320014 & 17.32 & 79.14 & BW & 7.9 & 3800 & 2432 & 96 & 53 & 182 & 1.0 & 457 & 12 & 9 \\
\hline 3 & RP_03 & Munipampula & 2320004 & 17.32 & 79.15 & TANK & 8.2 & 2200 & 1408 & 74 & 40 & 176 & 3.0 & 351 & 9 & 6 \\
\hline 4 & RP_04 & Munipampula & 2320004 & 17.32 & 79.17 & DW & 7.8 & 2300 & 1472 & 88 & 44 & 161 & 4.0 & 401 & 12 & 5 \\
\hline 5 & RP_05 & Palliwada & 2320005 & 17.35 & 79.17 & RIVER & 7.9 & 2800 & 1792 & 112 & 28 & 242 & 2.0 & 395 & 9 & 1 \\
\hline 6 & RP_06 & Palliwada & 2320005 & 17.33 & 79.17 & BW(HP) & 7.1 & 2000 & 1280 & 110 & 26 & 99 & 4.0 & 382 & 0 & 9 \\
\hline 7 & RP_07 & Bachuppala & 2320006 & 17.34 & 79.21 & DW & 7.3 & 2500 & 1600 & 163 & 38 & 168 & 1.0 & 563 & 0 & 8 \\
\hline 8 & RP_08 & Suraram & 2320007 & 17.35 & 79.23 & DW & 7.8 & 3100 & 1984 & 74 & 48 & 176 & 2.0 & 382 & 6 & 1 \\
\hline 9 & RP_09 & B.Thurkapalle & 2320008 & 17.36 & 79.23 & $\mathrm{BW}(\mathrm{HP})$ & 7.3 & 4400 & 2816 & 99 & 52 & 231 & 6.0 & 460 & 0 & 1 \\
\hline 10 & RP_10 & Peddabaigudem & 2320010 & 17.34 & 79.23 & BW & 7.2 & 2700 & 1728 & 122 & 66 & 134 & 5.0 & 575 & 0 & 1 \\
\hline 11 & RP_11 & Yennaram & 2320010 & 17.32 & 79.21 & DW & 7.7 & 1200 & 768 & 118 & 74 & 268 & 4.0 & 601 & 0 & 9 \\
\hline 12 & RP_12 & Kakkireni & 2320011 & 17.32 & 79.21 & BW & 7.0 & 3500 & 2240 & 143 & 76 & 221 & 2.0 & 669 & 0 & 1 \\
\hline 13 & RP_13 & Kakkireni & 2320011 & 17.30 & 79.20 & BW & 7.0 & 2200 & 1408 & 112 & 16 & 176 & 8.0 & 348 & 0 & 7 \\
\hline 14 & RP_14 & Iskilla & 2320013 & 17.29 & 79.05 & BW & 7.1 & 1300 & 832 & 41 & 16 & 65 & 4.0 & 169 & 9 & 5 \\
\hline 15 & RP_15 & Iskilla & 2320013 & 17.29 & 79.14 & BW & 7.6 & 700 & 448 & 116 & 42 & 13 & 6.0 & 461 & 0 & 1 \\
\hline 16 & RP_16 & Janampalli & 2320021 & 17.29 & 79.12 & BW & 7.3 & 800 & 512 & 147 & 57 & 12 & 2.0 & 600 & 0 & 2 \\
\hline 17 & RP_17 & Neernemla & 2320015 & 17.32 & 79.09 & DW & 7.5 & 3300 & 2112 & 161 & 134 & 38 & 2.0 & 952 & 0 & 1 \\
\hline 18 & RP_18 & Shobhanadripur & 2320002 & 17.35 & 79.10 & DW & 7.6 & 3600 & 2304 & 121 & 48 & 186 & 4.0 & 499 & 33 & 7 \\
\hline 19 & RP_19 & Laxmapur & 2320003 & 17.35 & 79.11 & DW & 7.2 & 5700 & 3648 & 186 & 76 & 221 & 2.0 & 777 & 0 & 6 \\
\hline 20 & RP_20 & Laxmapur & 2320003 & 17.34 & 79.10 & BW & 7.2 & 3100 & 1984 & 184 & 26 & 186 & 1.0 & 565 & 0 & 5 \\
\hline 21 & RP_21 & Neernemla & 2320015 & 17.31 & 79.09 & DW & 7.4 & 4800 & 3072 & 161 & 28 & 198 & 8.0 & 517 & 0 & 1 \\
\hline 22 & RP_22 & Kommaigudem & 2320020 & 17.27 & 79.09 & $\mathrm{BW}(\mathrm{HP})$ & 7.2 & 2100 & 1344 & 116 & 65 & 242 & 4.0 & 558 & 0 & 8 \\
\hline 23 & RP_23 & Ramannapet & 2320020 & 17.30 & 79.10 & BW & 7.7 & 1500 & 960 & 47 & 19 & 162 & 2.0 & 195 & 9 & 7 \\
\hline 24 & RP_24 & Bogaram & 2320017 & 17.30 & 79.08 & BW & 7.2 & 900 & 576 & 86 & 21 & 14 & 1.0 & 302 & 0 & 6 \\
\hline 25 & RP_25 & Bogaram & 2320017 & 17.30 & 79.07 & $\mathrm{BW}(\mathrm{HP})$ & 7.5 & 600 & 384 & 39 & 5 & 12 & 3.0 & 118 & 0 & 6 \\
\hline 26 & RP_26 & Bogaram & 2320017 & 17.31 & 79.07 & BW & 8.7 & 1500 & 960 & 55 & 14 & 102 & 4.0 & 195 & 9 & 6 \\
\hline 27 & RP_27 & Nidanpalli & 2320016 & 17.32 & 79.08 & BW & 7.3 & 3200 & 2048 & 129 & 56 & 198 & 6.0 & 551 & 0 & 9 \\
\hline 28 & RP_28 & Thummalagudem & 2320001 & 17.34 & 79.05 & TANK & 8.5 & 2100 & 1344 & 49 & 42 & 176 & 2.0 & 293 & 6 & 7 \\
\hline 29 & RP_29 & Thummalagudem & 2320001 & 17.33 & 79.05 & DW & 7.2 & 1900 & 1216 & 112 & 13 & 145 & 1.0 & 332 & 0 & 8 \\
\hline 30 & RP_30 & Yellanki & 2320018 & 17.30 & 79.04 & DW & 7.3 & 1600 & 1024 & 67 & 26 & 158 & 2.0 & 275 & 0 & 9 \\
\hline 31 & RP_31 & Yellanki & 2320018 & 17.30 & 79.02 & BW & 7.6 & 1000 & 640 & 51 & 9 & 86 & 4.0 & 164 & 6 & 1 \\
\hline 32 & RP_32 & Siripuram & 2320019 & 17.29 & 79.04 & BW & 7.2 & 1400 & 896 & 63 & 15 & 76 & 2.0 & 220 & 0 & 8 \\
\hline 33 & RP_33 & Siripuram & 2320017 & 17.29 & 79.08 & BW & 7.4 & 1600 & 1024 & 98 & 8 & 162 & 4.0 & 276 & 0 & 9 \\
\hline 34 & RP_34 & Siripuram & 2320019 & 17.27 & 79.06 & BW & 7.4 & 1100 & 704 & 41 & 24 & 22 & 6.0 & 200 & 0 & 6 \\
\hline 35 & RP_35 & Thummalagudem & 2320001 & 17.33 & 79.04 & BW & 8.8 & 2100 & 1344 & 74 & 28 & 162 & 2.0 & 300 & 24 & 7 \\
\hline 36 & RP_36 & Uthatoor & 2320012 & 17.28 & 79.17 & BW & 7.5 & 810 & 520 & 104 & 38 & 16 & 5.0 & 442 & 0 & 7 \\
\hline
\end{tabular}


Table 3

Chemical analysis of water samples collected during post-monsoon season

\begin{tabular}{|c|c|c|c|c|c|c|c|c|c|c|c|c|c|c|c|c|}
\hline S.N. & S_No & Village & DMV_Code & LAT & LONG & $\begin{array}{l}\text { Type of } \\
\text { Source }\end{array}$ & $\mathrm{pH}$ & EC & TDS & $\begin{array}{l}\mathrm{Ca} \\
+2\end{array}$ & $\begin{array}{l}\mathrm{Mg} \\
+2\end{array}$ & $\mathrm{Na}+$ & $\mathrm{K}+$ & TH & $\begin{array}{l}\mathrm{CO}^{-} \\
\end{array}$ & $\mathrm{HCC}$ \\
\hline 1 & RP_01 & Dubbaka & 2320014 & 17.31 & 79.14 & BW & 7.5 & 2813 & 1800 & 114 & 76 & 156 & 2.0 & 597 & 0 & 156 \\
\hline 2 & RP_02 & Dubbaka & 2320014 & 17.32 & 79.14 & BW & 7.8 & 3072 & 1966 & 116 & 66 & 186 & 4.0 & 561 & 0 & 201 \\
\hline 3 & RP_03 & Munipampula & 2320004 & 17.32 & 79.15 & TANK & 8.1 & 1992 & 1275 & 68 & 45 & 181 & 2.0 & 355 & 13 & 162 \\
\hline 4 & RP_04 & Munipampula & 2320004 & 17.32 & 79.17 & DW & 7.7 & 2189 & 1401 & 76 & 56 & 176 & 6.0 & 420 & 0 & 98 \\
\hline 5 & RP_05 & Palliwada & 2320005 & 17.35 & 79.17 & RIVER & 7.7 & 2563 & 1640 & 102 & 22 & 221 & 2.0 & 345 & 0 & 77 \\
\hline 6 & RP_06 & Palliwada & 2320005 & 17.33 & 79.17 & $\mathrm{BW}(\mathrm{HP})$ & 6.9 & 1859 & 1190 & 86 & 42 & 102 & 4.0 & 388 & 0 & 77 \\
\hline 7 & RP_07 & Bachuppala & 2320006 & 17.34 & 79.21 & DW & 7.3 & 2203 & 1410 & 126 & 34 & 148 & 4.0 & 455 & 0 & 178 \\
\hline 8 & RP_08 & Suraram & 2320007 & 17.35 & 79.23 & DW & 7.8 & 2906 & 1860 & 86 & 40 & 167 & 2.0 & 379 & 0 & 99 \\
\hline 9 & RP_09 & B.Thurkapalle & 2320008 & 17.36 & 79.23 & $\mathrm{BW}(\mathrm{HP})$ & 7.2 & 3828 & 2450 & 98 & 41 & 201 & 6.0 & 413 & 0 & 221 \\
\hline 10 & RP_10 & P. Gudem & 2320010 & 17.34 & 79.23 & BW & 7.2 & 2516 & 1610 & 126 & 58 & 146 & 2.0 & 553 & 0 & 121 \\
\hline 11 & RP_11 & Yennaram & 2320010 & 17.32 & 79.21 & DW & 7.7 & 1063 & 680 & 102 & 67 & 232 & 1.0 & 530 & 0 & 98 \\
\hline 12 & RP_12 & Kakkireni & 2320011 & 17.32 & 79.21 & BW & 6.8 & 3313 & 2120 & 122 & 72 & 209 & 4.0 & 601 & 0 & 126 \\
\hline 13 & RP_13 & Kakkireni & 2320011 & 17.30 & 79.20 & BW & 7.0 & 2158 & 1381 & 106 & 22 & 168 & 6.0 & 355 & 12 & 186 \\
\hline 14 & RP_14 & Iskilla & 2320013 & 17.29 & 79.05 & BW & 7.5 & 1047 & 670 & 56 & 28 & 98 & 4.0 & 255 & 14 & 88 \\
\hline 15 & RP_15 & Iskilla & 2320013 & 17.29 & 79.14 & BW & 7.2 & 3344 & 2140 & 86 & 38 & 66 & 4.0 & 371 & 0 & 76 \\
\hline 16 & RP_16 & Janampalli & 2320021 & 17.29 & 79.12 & BW & 7.3 & 2156 & 1380 & 121 & 38 & 22 & 2.0 & 459 & 21 & 222 \\
\hline 17 & RP_17 & Neernemla & 2320015 & 17.32 & 79.09 & DW & 7.5 & 1231 & 788 & 146 & 77 & 52 & 6.0 & 681 & 0 & 88 \\
\hline 18 & RP_18 & Shobhanadripuram & 2320002 & 17.35 & 79.10 & DW & 7.1 & 559 & 358 & 119 & 44 & 178 & 4.0 & 478 & 0 & 82 \\
\hline 19 & RP_19 & Laxmapur & 2320003 & 17.35 & 79.11 & DW & 7.1 & 753 & 482 & 151 & 71 & 186 & 6.0 & 669 & 0 & 121 \\
\hline 20 & RP_20 & Laxmapur & 2320003 & 17.34 & 79.10 & BW & 7.3 & 3266 & 2090 & 144 & 22 & 171 & 4.0 & 450 & 0 & 128 \\
\hline 21 & RP_21 & Neernemla & 2320015 & 17.31 & 79.09 & DW & 7.1 & 3444 & 2204 & 148 & 26 & 201 & 6.0 & 477 & 0 & 256 \\
\hline 22 & RP_22 & Kommaigudem & 2320020 & 17.27 & 79.09 & $\mathrm{BW}(\mathrm{HP})$ & 7.1 & 3922 & 2510 & 94 & 46 & 228 & 2.0 & 424 & 0 & 151 \\
\hline 23 & RP_23 & Ramannapet & 2320020 & 17.30 & 79.10 & BW & 7.5 & 2828 & 1810 & 56 & 26 & 152 & 4.0 & 247 & 0 & 128 \\
\hline 24 & RP_24 & Bogaram & 2320017 & 17.30 & 79.08 & BW & 7.2 & 4047 & 2590 & 98 & 18 & 26 & 6.0 & 319 & 0 & 146 \\
\hline 25 & RP_25 & Bogaram & 2320017 & 17.30 & 79.07 & $\mathrm{BW}(\mathrm{HP})$ & 7.3 & 1938 & 1240 & 42 & 16 & 32 & 2.0 & 171 & 0 & 58 \\
\hline 26 & RP_26 & Bogaram & 2320017 & 17.31 & 79.07 & BW & 8.4 & 1219 & 780 & 66 & 18 & 121 & 4.0 & 239 & 26 & 52 \\
\hline 27 & RP_27 & Nidanpalli & 2320016 & 17.32 & 79.08 & BW & 7.2 & 775 & 496 & 108 & 69 & 178 & 6.0 & 554 & 0 & 168 \\
\hline 28 & RP_28 & Thummalagudem & 2320001 & 17.34 & 79.05 & TANK & 8.3 & 534 & 342 & 52 & 56 & 168 & 2.0 & 360 & 22 & 88 \\
\hline 29 & RP_29 & Thummalagudem & 2320001 & 17.33 & 79.05 & DW & 7.1 & 1525 & 976 & 108 & 18 & 152 & 6.0 & 344 & 0 & 88 \\
\hline 30 & RP_30 & Yellanki & 2320018 & 17.30 & 79.04 & DW & 7.2 & 763 & 488 & 68 & 33 & 144 & 2.0 & 306 & 0 & 76 \\
\hline 31 & RP_31 & Yellanki & 2320018 & 17.30 & 79.02 & BW & 7.5 & 531 & 340 & 69 & 12 & 99 & 6.0 & 222 & 0 & 98 \\
\hline 32 & RP_32 & Siripuram & 2320019 & 17.29 & 79.04 & BW & 7.2 & 1281 & 820 & 58 & 24 & 71 & 4.0 & 244 & 0 & 76 \\
\hline 33 & RP_33 & Siripuram & 2320017 & 17.29 & 79.08 & BW & 7.4 & 3094 & 1980 & 79 & 18 & 156 & 4.0 & 271 & 0 & 72 \\
\hline 34 & RP_34 & Siripuram & 2320019 & 17.27 & 79.06 & BW & 7.3 & 2047 & 1310 & 38 & 26 & 28 & 2.0 & 202 & 0 & 66 \\
\hline 35 & RP_35 & Thummalagudem & 2320001 & 17.33 & 79.04 & BW & 8.2 & 1733 & 1109 & 78 & 56 & 158 & 6.0 & 425 & 18 & 129 \\
\hline 36 & RP_36 & Uthatoor & 2320012 & 17.28 & 79.17 & BW & 7.5 & 801 & 512 & 103 & 40 & 14 & 3.0 & 438 & 0 & 72 \\
\hline
\end{tabular}

\section{Fluoride}

As per WHO and BIS guidelines, Allowable fluoride concentrations in potable waters is $1.5 \mathrm{mg} / \mathrm{l}$. Consumption of high fluoride water can cause dental, mild skeletal, and crippling skeletal fluorosis (WHO; 2004). Fluoride in the water ranged from 0.30 to $3.00 \mathrm{mg} / \mathrm{Lin}$ the study area with an average of $1.42 \mathrm{mg} / \mathrm{L}$ was found. An average value of fluoride for all the sources is calculated for each habitation. From the collected data, the fluoride distribution maps were prepared 
using Spatial Analyst Tools (SAT)adopting Inverse Distance Weightage (IDW) method. Based on fluoride content in drinking water, the map is divided into three zones. That are Desirable $(<1.00 \mathrm{mg} / \mathrm{L})$, Permissible $(1.50-3.00 \mathrm{mg} / \mathrm{L})$ and Non Potable $(>3.00 \mathrm{mg} / \mathrm{L})$.

Figures 4 and 5 shows spatial fluoride distribution of the study area based on the collected water samples in pre and post monsoon seasons respectively. The elevated level $(3-5 \mathrm{mg} / \mathrm{L})$ of fluoride was observed at isolated places like in Dubbaka and Siripuram villages in central and south region of the Mandal. The people from these villages are at risk of dental/skeletal fluorosis.

Even, Ramannapet, Kommaigudem and Nidanpalli showed marginally high concentration of fluoride (1.5-3.0 mg/L). From Figs. 4 and 5, the spatial distribution of fluoride is lower during post-monsoon in some places when compared with pre monsoon collections. The dilution of fluoride with recharged rain water might be the reason. The fluoride concentration in groundwater can be diluted with surface water and its infiltration into downstream.

The fluoride content in groundwater varied in the study area due to the accessibility of fluorine-bearing minerals to the circulating water, the leaching and weathering activities. The fluoride concentration is more in shallow or moderately weathered Pediplains, Alkali Feldspar Granite, and Grey Biotite Granite which located in western part and around the mandal. Even, high concentration of fluoride was observed at isolated places in granite and dolerite, the west side of the mandal. Fluoride in the exogenic cycle of the fluorosis belt is almost contributed by the granitic and pegmatitic rocks. Above discussed fluoride bearing minerals of these rocks are the acid soluble minerals such as fluorite, fluorapatite, hornblende, mica, epidote etc. These minerals are responsible for high concentration of fluoride in natural waters, as they release fluoride under normal temperature pressure conditions. Furthermore, $\mathrm{pH}$ of water increases the releasing of fluorides from fluoride-bearing minerals during the weathering processes within the aquifers (Saxena and Ahmed 2001).

The fluoride minerals are abundant in the granite and gneiss rocks present in the mandal. Hence, the concentration of fluoride in groundwater is the highest in those villages present on the northern and southern parts and in isolated patches of the study area. The distribution of fluoride in groundwater depends on the amount of fluoride in the rocks or soils, the contact time of the water with the rocks, temperature, rainfall, vegetation and oxidation and reduction reactions. The percolating water dissolves the salts from soils, the fluoride concentration of groundwater may be higher than that during dry periods. The other factor is the amount of fluoride in the water depends on the degree of granitic rock weathering of the area (APSRAC, 1997).

\section{Hydrogen lon Concentration $(\mathrm{pH})$}

$\mathrm{pH}$ is a measure of the relative acidity or alkalinity of a sample. It is equal to the negative logarithm of the hydrogen ion activity in moles per liter (-log aH+). The pH scale ranges from 1 to 14 , with 1 being the most acidic and 14 being the most alkaline. Solutions with a pH less than 7.0 are typically classified as acidic; those greater than 7.0 as alkaline

The $\mathrm{pH}$ values in the Study area varied from 6.92 to 8.78 with an average of 7.51 . $\mathrm{pH}$ of all the analyzed samples were within the permissible limiting value of 6.5-8.5 given by the BIS (2003).

\section{Total Hardness}

Water total hardness $[\mathrm{TH}]$ is caused by various dissolved salts of calcium, magnesium or iron and expressed as $\mathrm{mg} / \mathrm{l}$ of $\mathrm{CaCO} \neg 3$. The total hardness $(\mathrm{TH})$ in ppm was determined by following equation (Todd 1980):

$\mathrm{TH}=2: 497 \mathrm{Ca} 2++4: 115 \mathrm{Mg} 2+$

According to Durfor and Becker's (1964) classification of TH (i.e. 0-60, soft; $61-120$, moderately hard; $121-180$, hard; and > 180 very hard). In the present study area the hardness levels measured were in the range of $118 \mathrm{mg} / \mathrm{l} 8$ to $952 \mathrm{mg} / \mathrm{l}$ with a mean value of $418 \mathrm{mg} / \mathrm{l}$.

\section{Electrical conductivity}

Electrical Conductivity [EC] is one of the important indices of water quality, which gives the measure of the dissolved salts and salinity, the parameters imparting unpalatable taste to groundwater (Langengger, 1990). This has a significant impact on the user's acceptance of such water resources (EdetAe, 1993). Conductivity is the measure of a solution's ability to transfer electric current. The higher the conductivity of a solution, greater the potential to transfer electrical current. The conductance of a solution is dependent on three parameters: temperature (temperature increases the conductivity of a solution), nature of ions present, and quantity of ions present. Multivalent ions (i.e, those with valency greater than one) contribute more to conductivity than monovalent (valency one) charged ions. Most often, equipment for measuring conductivity gives results based on a temperature of $25^{\circ} \mathrm{C}$. Such measurements can be adjusted to correct for other ambient temperatures (Peavy, et al., 1985). Because hydrogen ions ( $\mathrm{H}+)$ and hydroxyl ions $(\mathrm{OH}-)$ exhibit higher conductance, due to their increased mobility, extreme pH levels are an important consideration when measuring conductance (Sawyer, et. al., 1994). The higher EC of the water samples is the result of ion exchange and dissolution of the aquifer material (Sanchez-Perez and Tremolieres, 2003).

The study area groundwater samples have EC in the range 600 to 5700 with an average of $2348 \mu \mathrm{S} / \mathrm{cm}$. The maximum limit of EC in drinking water is prescribed as $1,500 \mu \mathrm{s} / \mathrm{cm}$ as per WHO standard. About half of the samples collected showed EC values more than permissible limit. EC distribution is found to be similar to that of $\mathrm{Cl}-, \mathrm{SO} 42-, \mathrm{HCO} 3-$ and $\mathrm{K}+$ distribution patterns, indicating it is positively correlated with these ions.

\section{Total dissolved Solids (TDS)}

TDS refers to the total dissolved solids present in the water. Measurement of conductivity is often used as an indirect method of estimating the dissolved solids content of a solution. (Chapra, 1997) reports a relationship between total dissolved solids and conductivity.

$\operatorname{TDS}(\mathrm{mg} / \mathrm{L})=0.64 \times$ Conductivity $(\mu \mathrm{mhos} / \mathrm{cm})$ 
As per the (BIS, 2003) specification for drinking water, $500 \mathrm{mg} / \mathrm{l}$ is treated as desired limit and $2000 \mathrm{mg} / \mathrm{l}$ of TDS is treated as maximum permissible limit. Higher concentrations of TDS decrease the palatability and may cause gastro-intestinal irritation in human and may also have laxative effect particularly upon transits. It is a well-known fact that the recharging water during its downward movement through the zone of aeration dissolves mineral matter thus enriching itself in total dissolved solids. This dissolution continues even in the zone of saturation due to rock-water interaction during the residence time of groundwater in the host rock. The enrichment of TDS is also governed by evaporation of water. In this study area all the samples have TDS between 384 and $3648 \mathrm{mg} / \mathrm{l}$ with an average value of $1503 \mathrm{mg} / \mathrm{l}$.

\section{Permeability Index (PI)}

The Permeability Index (PI) values also depicts suitability of groundwater for irrigation purposes, since long-term use of irrigation water can affect the soil permeability, influenced by the $\mathrm{Na}^{+}, \mathrm{Ca}^{2+}, \mathrm{Mg}^{2+}$ and $\mathrm{HCO}_{3}{ }^{-}$contents of the soil. The PI can be expressed as

$$
P I=\frac{(\mathrm{Na}+\mathrm{K})+\sqrt{\mathrm{HCO}_{3}}}{\mathrm{Ca}+\mathrm{Mg}+\mathrm{Na}+\mathrm{K}} \times 100
$$

$=$ The concentrations are reported in meq/I. (Doneen, 1964) developed a criterion for assessing the suitability of water for irrigation based on PI, where waters can be classified as classes I, II, and III. The PI of the area varied from 53.81 to 122.32 and the average value is 72.10 .

\section{Piper Classification:}

The trilinear diagrams of Piper are very useful in determining chemical relationships in groundwater in more definite terms than is possible with other plotting methods (Piper, 1953). Piper's trilinear diagram method is used to classify the groundwater, based on basic geochemical characters of the constituent ionic concentrations. The chemical data of the groundwater samples collected from the study area are plotted in the Piper's diagram (Fig. 6). The chemical subdivisions $1,2,3,4,5,6,7,8$ and 9 indicate that the alkaline ( $\mathrm{Ca}+$ and $\mathrm{Mg}+$ ) and strong acids mainly dominate the chemical characteristic of the groundwater. Based on Piper classification all samples are fall in the IV category (Strong acids exceeds weak acids) in pre and post-monsoon periods.

\section{US salinity Laboratory diagram:}

The US Salinity Laboratory Staff, 1954) proposed a diagram for studying the suitability of groundwater for irrigation purposes by using the SAR values on vertical axis and electrical conductivity on horizontal axis.

The diagram is divided into four distinct classifications both horizontally and vertically. On horizontal axis the salinity hazard classification is divided into low salinity (C1), medium salinity (C2), high salinity (C3) and very high salinity (C4). Likewise on vertical axis sodium hazard classification is divided into low sodium water (S1), medium sodium water (S2), high sodium water (S3) and very high sodium water (S4). Figure 7 shows Richards Diagrams classification of irrigation water during pre and post monsoon period respectively.

It is clear from the Fig. 7 that the groundwater samples of the study area out of 36samples fall under Majority of samples are fall in the S1C3 and S2C4 category in pre and post-monsoon periods.

\section{Recommendations \& observations}

It is important to educate every citizen about the fluoride toxicity and the necessity of avoiding fluoride consumption. The intake of fluoride above the permissible limit in drinking water is the major reason for fluorosis disease in some parts of the study area. It is encouraged that Taking safe drinking water with sufficient dietary food in order to avoid fluorosis disease. It should be identified the fluoride affected areas with the help of scientific mapping and watersheds are proposed in the area. It is important to look for holistic and people-centred approaches for water management.

The occurrence groundwater in the study area is completely controlled by rainfall and canal whereas the quality of the water controlled by the terrain features like landforms, lithology, soil, drainage, topography, etc. The information provided in the groundwater prospect zones helps in identifying the areas suitable for artificial recharge. Tremendous pressure on groundwater for domestic, agriculture and industrial uses results in pollution of groundwater resources. In the future, the limited resources will not be able to meet out the water demand qualitatively and quantitatively for next generation. With scientific guidelines, watersheds to be constructed on Fast Track basis. Groundwater management and artificial recharge structures will be helpful for recharging of groundwater to make the existing bore wells and dug wells sustainable.

Table 4. Number of Samples falling in different Areas of Diamond shaped field of Piper Diagram 


\begin{tabular}{|c|l|c|c|}
\hline $\begin{array}{l}\text { Sl. } \\
\text { No. }\end{array}$ & Description & $\begin{array}{l}\text { Number } \\
\text { of Samples Pre mon }\end{array}$ & $\begin{array}{l}\text { Number } \\
\text { of Samples Post mon }\end{array}$ \\
\hline 1. & Alkaline earths exceeding Alkalies & 20 & 23 \\
\hline 2. & Alkalies exceeds Alkaline earths & 16 & 13 \\
\hline 3. & Weak acids exceeds strong acids & - & - \\
\hline 4. & Strong acids exceeds weak acids & 36 & - \\
\hline 5. & Carbonate hardness exceeds 50\% & - & 13 \\
\hline 6. & Non-carbonate- hardness exceeds 50\% & 8 & - \\
\hline 7. & Non carbonate Alkali & 16 & 17 \\
\hline 8. & Carbonate Alkali & - & \\
\hline 9. & No on Cation-Anion pair exceeds 50\% & 12 & - \\
\hline
\end{tabular}

\section{Conclusions}

The Spatial distributions of fluoride maps were prepared with the help of the Remote Sensing Imaginary (RSI) and Geographical Information System (GIS) techniques. The techniques are very useful in identifying of groundwater prospect zones in various hydro-geomorphic units. The range of fluoride in the study area varied from 0.6 to $5.6 \mathrm{ppm}$. Based on fluoride levels, the well water is unsuitable for drinking. The main factors that control the quality of water are associated with lithology and soil. The arid climate with high evaporation and insignificant natural recharge might have accelerated the increase in fluoride concentration in the groundwater of this area. The main sources of fluoride in natural waters are fluorite and fluor-apatite, as well as micas and hornblende in which the fluoride ion replaces the hydroxyl group.

Based on fluoride content in groundwater the map is divided into three zones. The high fluoride content in the groundwater is correlated with the fluoride bearing rocks of the study area.It was observed that fluoride contamination in the water is more in high yielding Hydrogeomorphic units as compared to low yielding Hydrogeomorphic units. The periodical drought and arid climate of the region increases incidence of fluoride in the groundwater resources. The constructions of rain water harvesting structures are proposed to minimize fluoride content in drinking water.

\section{Declarations}

\section{Acknowledgments}

The Authors thank to Rural Development Society, Hyderabad for providing financial support to carry out the study.

\section{References}

1. APSRAC, 1997. "Integrated Study to Combat Drought, Anantapur District, Andhra Pradesh", Project Report, 102p.

2. APHA (1992). Standard methods for the examination of water and wastewater (p. 326). Washington: American Public Health Association.

3. Bhagavan, S.V.B.K. and Raghu, V. 2005. "Utility of check dams in dilution of fluoride concentration in groundwater and the resultant analysis of blood serum and urine of villagers, Anantapur District, Andhra Pradesh, India”. Environmental Geochemistry and Health. Vol.27, pp.97-108.

4. CGWB (1999), Hydrogeological Framework and Development Prospects of Ranga Reddy District, Andhra Pradesh, Central Groundwater Board, Southern Region, Hyderabad, Ministry of Water Resources, Government of India

5. Gibbs, R. J. (1970). Mechanisms controlling worlds water chemistry. Science, 170, 1088-1090.

6. Indian Standards Institution (1992), Indian standard for drinking water ISO 10500.

7. NRSA (2007), Groundwater Prospects Mapping using Remote Sensing Techniques and Geographic Information System under Rajiv Gandhi national drinking water mission (RGNDWM), Technical Manual, National Remote Sensing Agency, Department of Space, Government of India (2007)

8. NRSA (2013), Groundwater Quality Mapping for Rajiv Gandhi national drinking water mission (RGNDWM) - Methodology Manual, National Remote Sensing Agency, Department of Space, Government of India (2013)

9. NRSA (2013), Groundwater Quality Mapping for Rajiv Gandhi national drinking water mission (RGNDWM) - Methodology Manual, National Remote Sensing Agency, Department of Space, Government of India (2013)

10. Prakash, P., Kumar Das, A., and Sandilya, C. V. S.: Study Relating to the Spatial Distribution of Groundwater Quality for Different Elements using Legacy Data of RWS\&S, Andhra Pradesh, India, Int. Arch. Photogramm. Remote Sens. Spatial Inf. Sci., XL-8, 383-390, doi: 10.5194/isprsarchives-XL-8-383-2014, 2014.

11. Raghunath HM (1987) Groundwater. Wiley-Eastern Ltd., New Delhi.

12. RamamohanaRao, N. V., SuryaprakasaRao, K., \&Schulling, R. D. (1993). Fluorine distribution in waters of Nalgonda District, Andhra Pradesh, India. Environmental Geology, 21, 84-89.

13. Sabins, F. F., (1997), Remote Sensing Principles and Interpretation, W. H. Freeman \& Company., Newyork

14. Thornbury, W. D. (1984). Principles of Geomorphology, Wiley Eastern Limited, New Delhi Todd DK. (2007), Groundwater Hydrology, Wiley- India Edition, 15. SubbaRao, N., \& John Devadas, D. (2003). Fluoride incidence in groundwater in an area of peninsular India. Environmental Geology, 45, $243-251$. 
16. Susheela, A. K. (1999). Fluorosis management programme in India. Current Science, 77, 1250-1256. Susheela, A. K. (2001). A treatise on f luorosis (p.

15). Delhi: Fluorosis Research and Rural Development Foundation.

17. WHO (2004). Guidelines for drinking water quality (p. 515). Geneva: World Health Organization.

18. Wodeyar, B. K., \&Sreenivasan, G. (1996). Occurrence of fluoride in the groundwaters and its impact in Peddavankahalla basin, Bellary district, Karnataka A preliminary study. Current Science, 70, 71-73.

19. Piper, A. M. (1953). A graphic procedure in the geochemical interpretation of water analysis. Washington, DC: USGS, Groundwater note 12.

20. Saxena, V. K., \& Ahmed, S. (2001). Dissolution of fluoride in groundwater: A water-rock interaction study. Environmental Geology, 40, 1084-1087

\section{Figures}

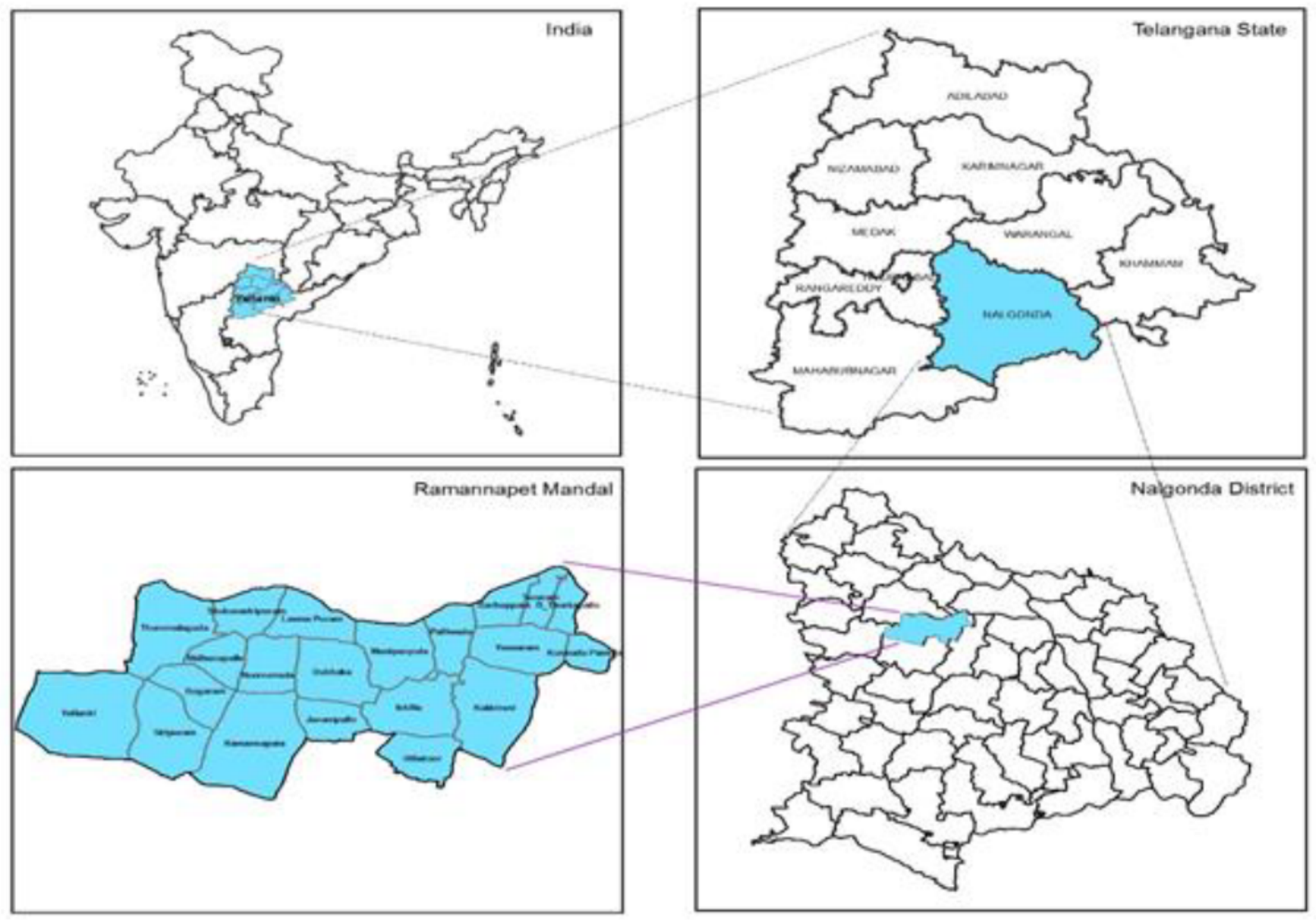

Figure 1

The location map of the present study area 


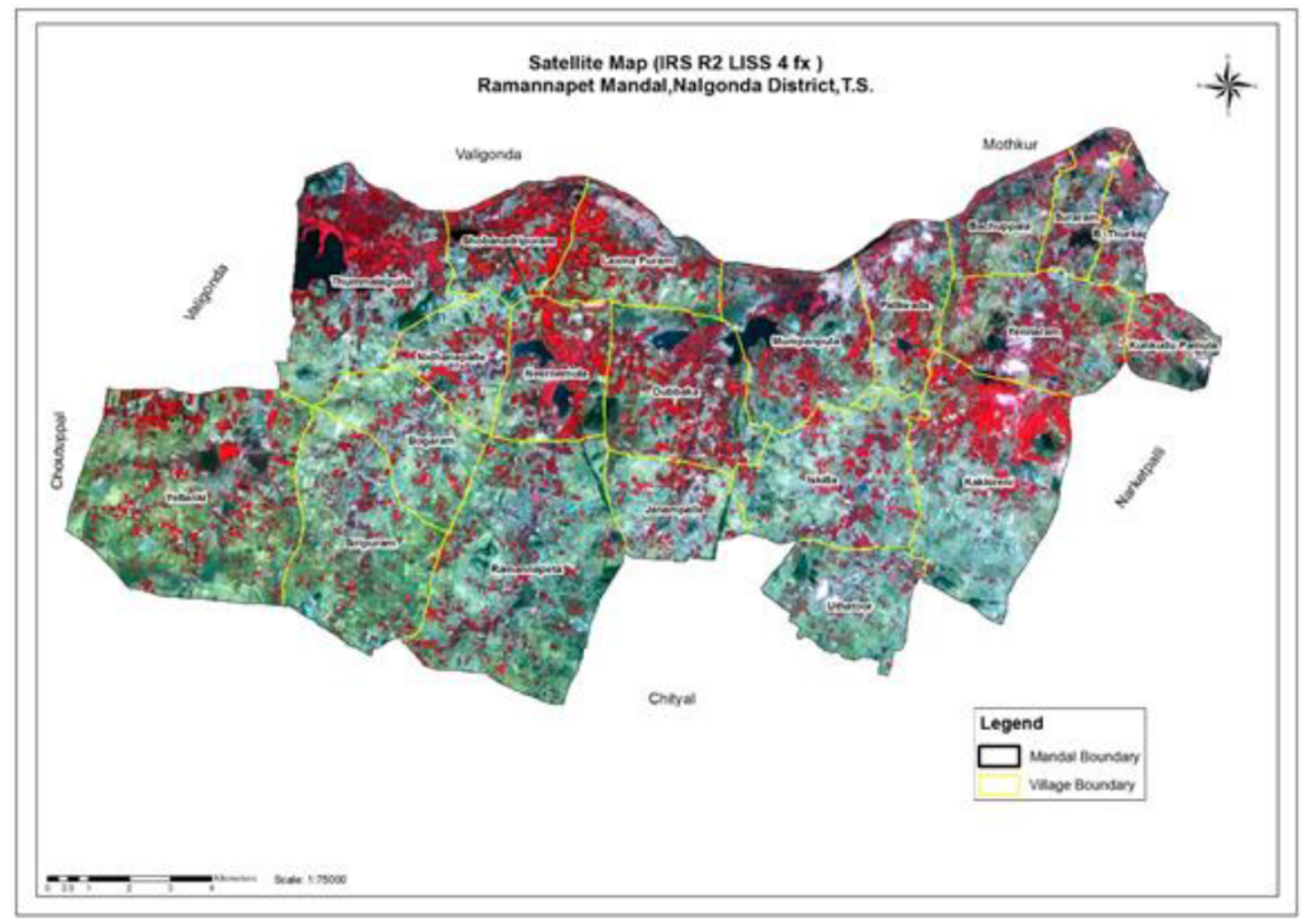

Figure 2

Satellite Map of the Study Area 


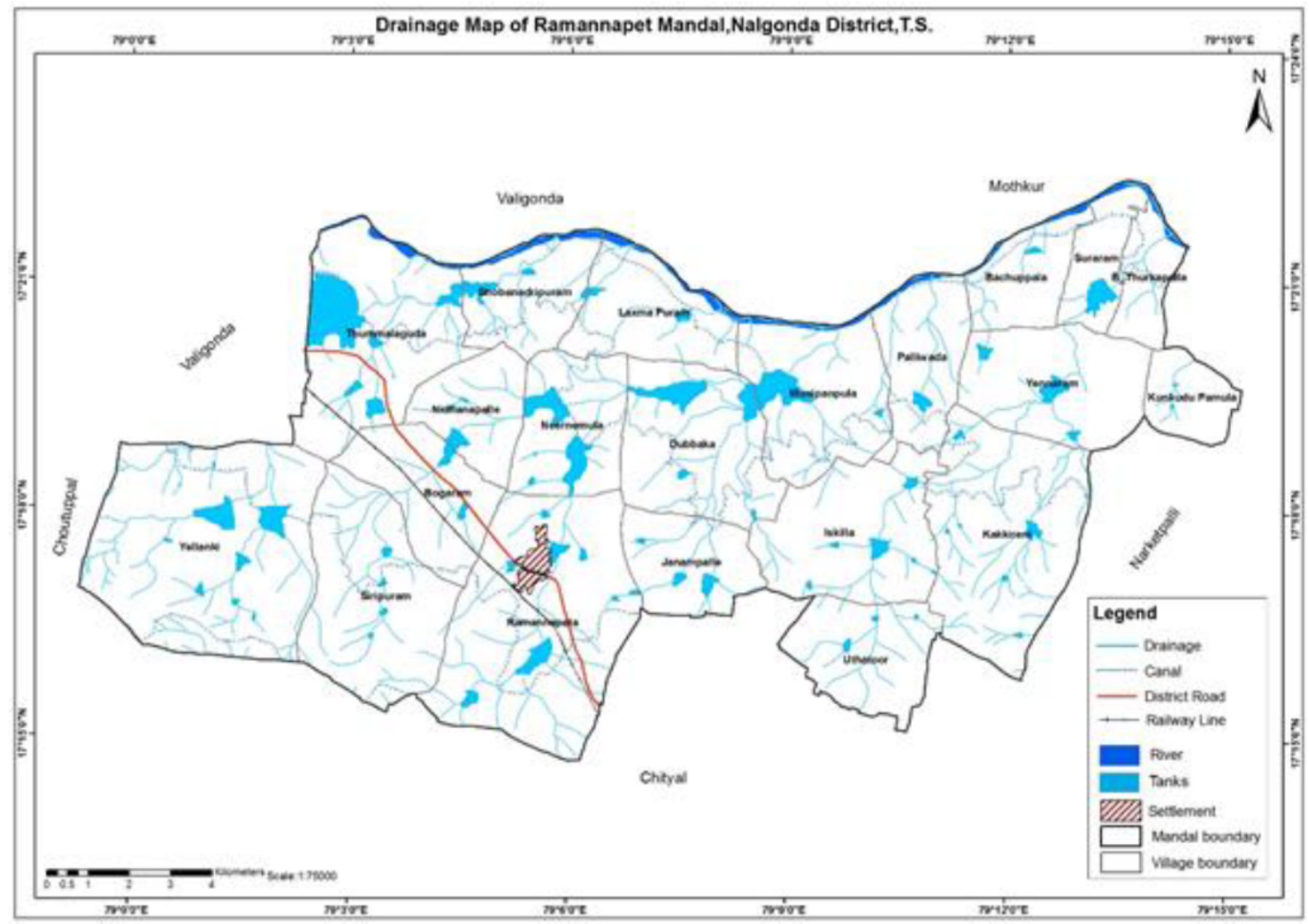

Figure 3

Drainage Map of the Study Area 


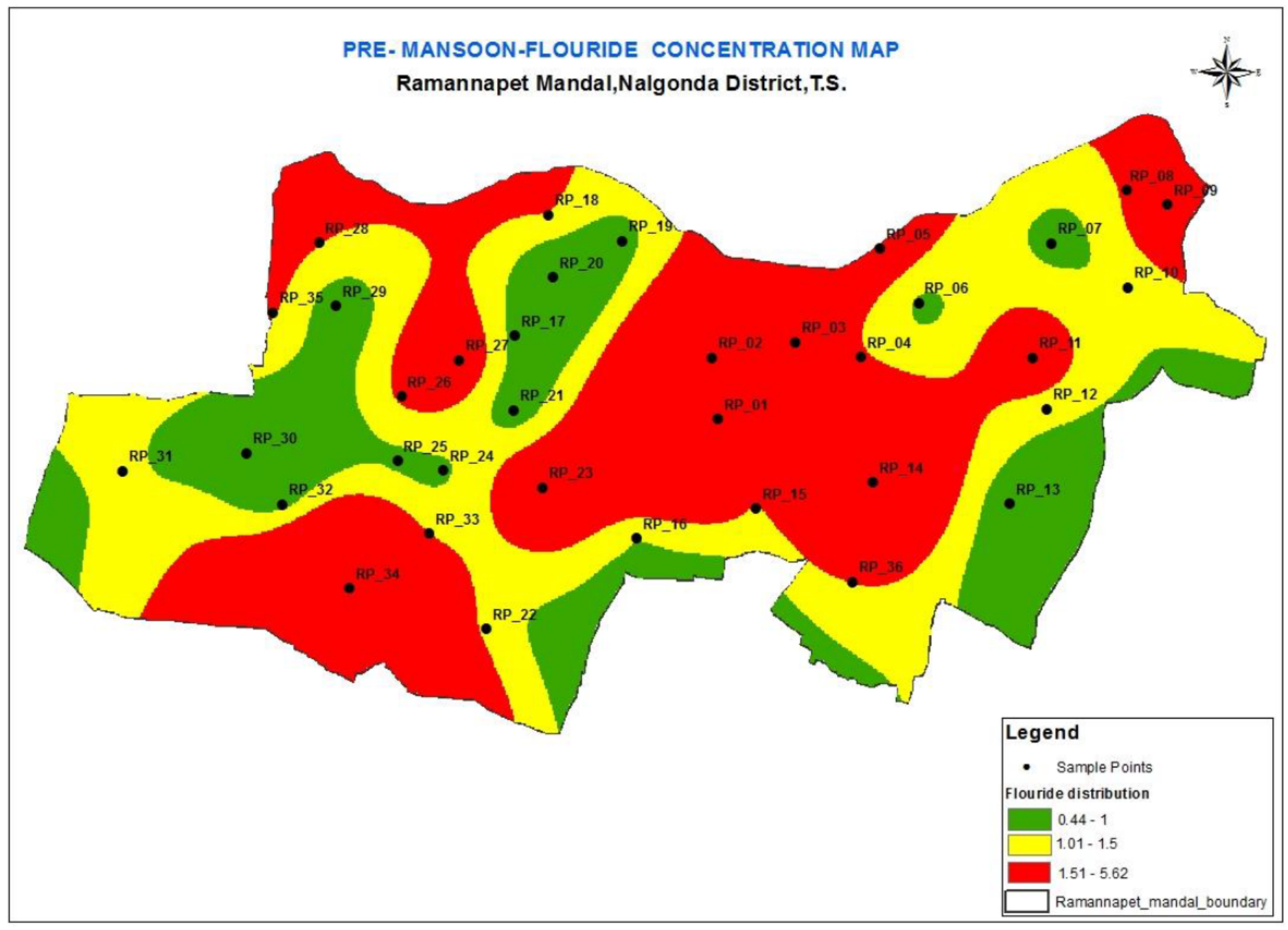

Figure 4

Spatial distribution of fluoride during pre-monsoon season. 


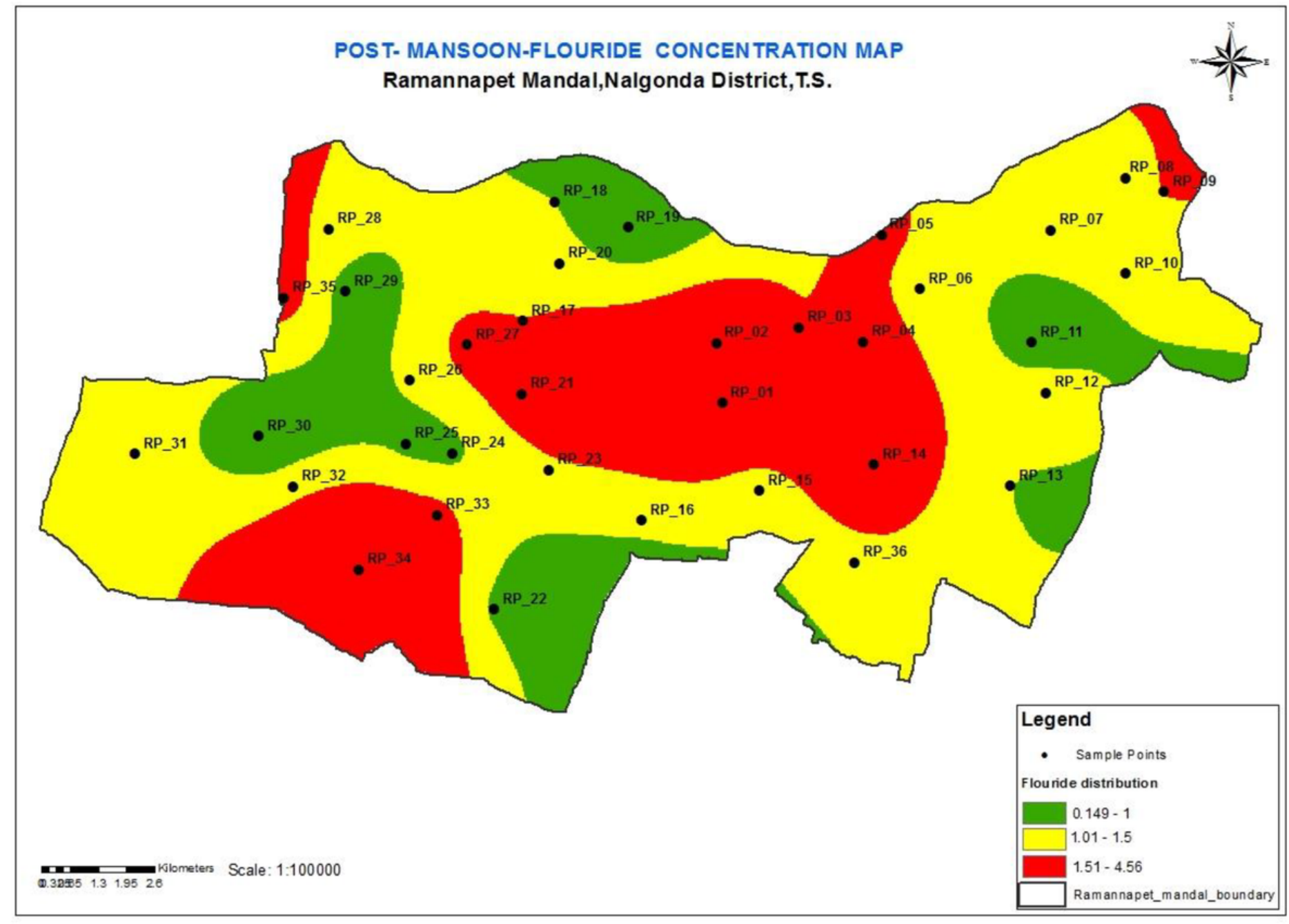

Figure 5

Spatial distribution of fluoride during post monsoon season
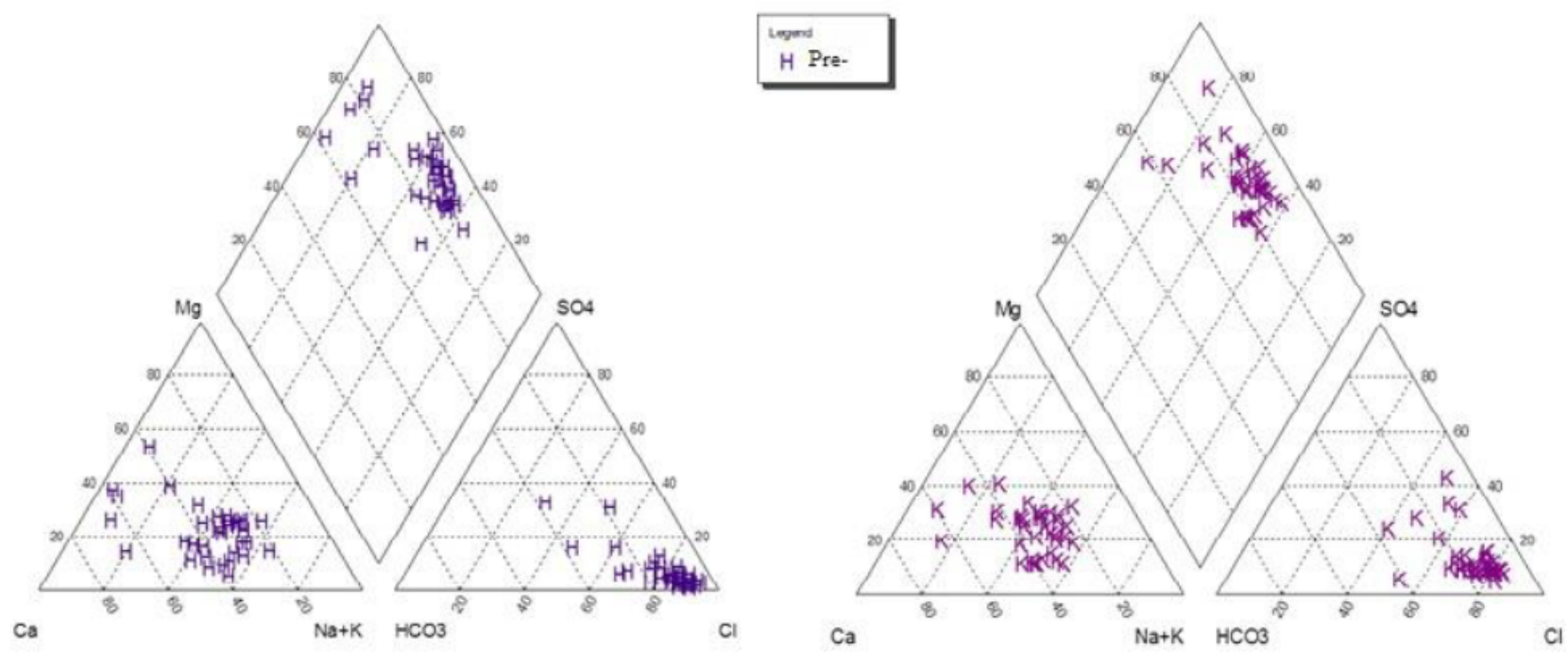

Figure 6

Piper classification of the study area 

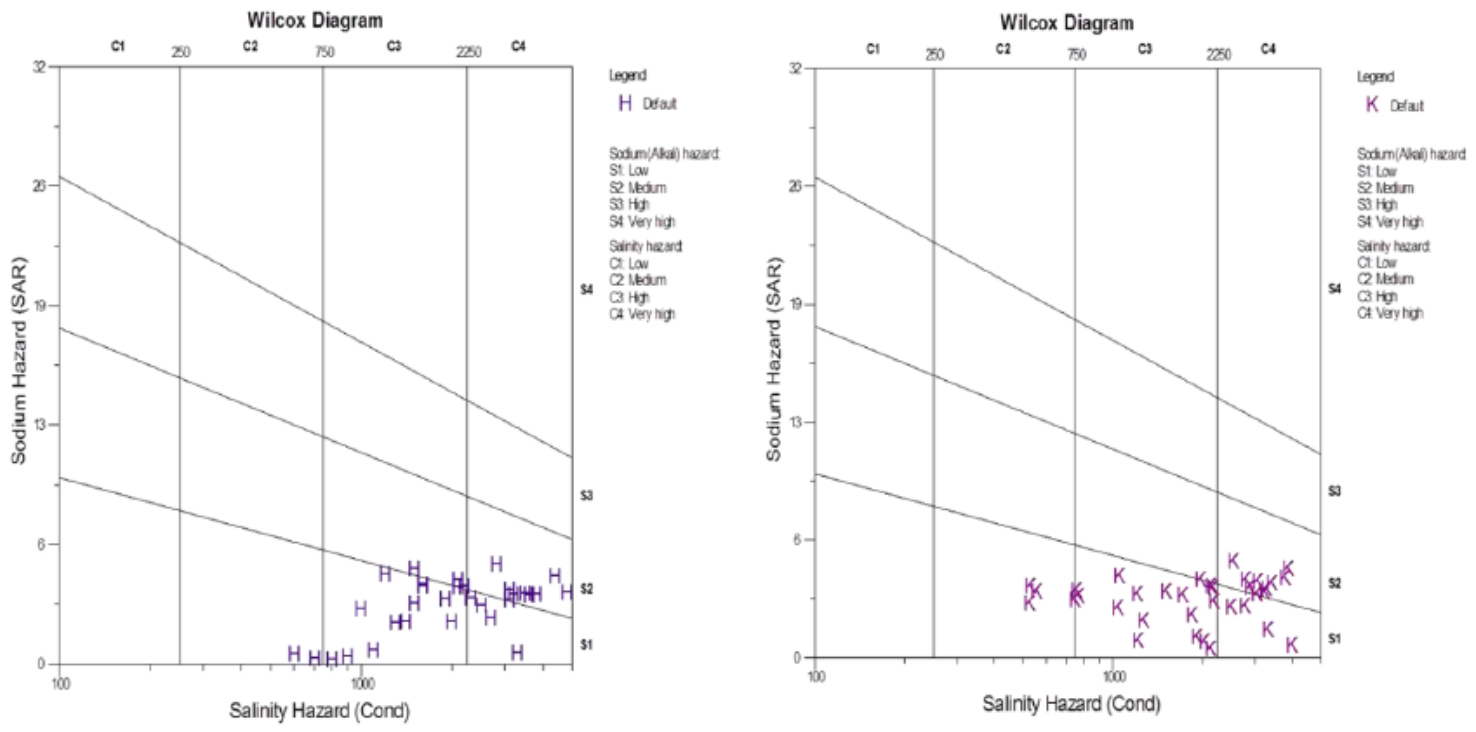

Figure 7

US salinity Laboratory diagram 